\title{
Pollination biology of large cardamom (Amomum subulatum Roxb.) with special emphasis on honey bees (Apis spp.) and bumble bees (Bombus spp.) pollinators
}

\author{
Ghanashyam Sharma ${ }^{1}$ Uma Partap ${ }^{2}$. Durga P. Sharma ${ }^{1}$
}

Received: 12 December 2018 / Revised: 2 December 2019 / Accepted: 2 December 2019 / Published online: 23 March 2020

(C) The Author(s) 2020

\begin{abstract}
We studied pollination ecology of large cardamom (Amomum subulatum) in three altitudinal gradients $(1100,1500,2000 \mathrm{~m})$ in the Sikkim Himalaya, with the hypothesis that both honey bees (Apis spp.) and bumble bees (Bombus braviceps, B. haemorrhoidalis) contribute to pollination and enhance yield. We placed honey bees colonies in cardamom stands, studied pollination within $50 \mathrm{~m}$ radius, $250 \mathrm{~m}$ away from it; and under control nets restricting pollinators. Honey bees showed highest number of floral visits $\left(19.24 \pm 4.23\right.$ per $\left.12 \mathrm{~m}^{2}\right)$ within $50 \mathrm{~m}$ than bumble bees $\left(13.87 \pm 3.12\right.$ per $\left.12 \mathrm{~m}^{2}\right)$. In $250 \mathrm{~m}$ stand, bumble bees visits $\left(20.57 \pm 5.31\right.$ per $\left.12 \mathrm{~m}^{2}\right)$ were higher than honey bees $\left(9.44 \pm 2.54\right.$ per $\left.12 \mathrm{~m}^{2}\right)$. Pollen removal by honey bees and bumble bees was 30-40\% and 50-70\% of the total pollen, respectively. Time spent across sites and treatments by honey bees ranged higher (12.87-36.25 s flower $\left.{ }^{-1}\right)$, than bumble bees $\left(4.60-27.80 \mathrm{~s} \mathrm{flower}^{-1}\right)$. Visitation of bees increased with increasing number of cardamom flowers and showed positive correlation $\left(r^{2}=0.46-0.55, P<0.001\right)$. Number of capsules per spike, capsule/seed weight, and gross agronomic yield was highest within $50 \mathrm{~m}$, lower in $250 \mathrm{~m}$ and lowest in control confirming that honey bees pollinated stand had higher yield. The study also confirmed that both honey bees and bumble bees were pollen collectors and pollination is by-product of their foraging activity on the flowers. This study suggests new insight on contribution of honey bees to large cardamom pollination and further research is needed for pollinators-large cardamom interaction.
\end{abstract}

Keywords Bumble bees $\cdot$ Honey bees $\cdot$ Large cardamom $\cdot$ Pollination biology $\cdot$ Sikkim himalayas

\section{Introduction}

Large cardamom (Amomum subulatum Roxb.) is an important perennial cash crop sympatric to sub-tropical and temperate agro-climatic zones (400-2400 m) of the Eastern Himalayan region including Nepal and Bhutan (Sharma et al. 2016a). It is an economically valuable, ecologically adaptive, and agro-climatically suitable perennial cash crop grown under tree shade in the eastern Himalayas. In the past few years, the worldwide production of large cardamom has fallen drastically due to several factors including diseases

Ghanashyam Sharma

banstolag@gmail.com

1 The Mountain Institute India, Below Dr. Dhakal's Clinic, Tadong Daragaon, Gangtok, Sikkim 737101, India

2 International Centre for Integrated Mountain Development, Khumaltar, Lalitpur, G.P.O. Box 3226, Kathmandu, Nepal
(Singh and Pothula 2013; Sharma et al. 2016a), and decline of pollinator species (Singh et al. 2011; Sharma 2013; Partap et al. 2014; Sharma et al. 2016a, b). Around 15 years ago, Sikkim was the major producer of large cardamom. Since then Nepal has been recognized as a major producer and exporter of cardamom, second only to Sikkim (Durbeck and Torstan 2010; Chapagain et al. 2014; Partap et al. 2014). Of the total 111,830 households in Sikkim, 16,037 $(14.34 \%)$ have large cardamom plantations on their farms. In Sikkim, around $29 \%$ of the total household revenue in the cardamom growing areas comes from the sale of large cardamom (Sharma et al. 2016a). The seeds of large cardamom have properties similar to those of small cardamom (Elettaria cardamomum, family Zingiberaceae) and are used as a condiment for culinary and other preparations. The seeds contain 2-3\% essential oils, which possess medicinal properties and are used as adjuncts to various medicinal preparations (Gupta et al. 1984). As the fruits and seeds are the economic products, effective pollination is a prerequisite for 
fruit and seed set, and to a large extent determines the yield. In spite of its economic importance, there are hardly any studies on the pollination biology of this species, except for a preliminary report implicating honey bees as pollinators (Verma 1987).

Efficient pollination is a major limiting factor for stability of yield of several economically important crops species (Allen-Wardell et al. 1998) including large cardamom (Sinu and Shivanna 2007). Bumble bees (Bombus braviceps and Bombus haemorrhoidalis) are reported to be the most efficient pollinators of large cardamom till date, while honey bees have been reported as pollen robber, which leave $70 \%$ of large cardamom flowers un-pollinated (Sinu and Shivanna 2007; Sinu et al. 2007; Kishore et al. 2011; Deka et al. 2011; Kishore et al. 2012). Interestingly, Sharma (2013), and Partap et al. (2014) have reported the perception of farmers of the Sikkim Himalaya that honey bees are in fact good pollinators for large cardamom, and are also traditionally reared by farm-households. A study carried out by Chaudhary and Kumar (2000) on pollination by honey bees small cardamom (Elettaria cardamomum) flowers had confirmed that honey bees pollination resulted in better quality capsules of uniform shape and bigger size. Conservation of pollinators has become crucial for high-value cash crop cultivation and for maintaining the genetic resources in cultivated systems. One such example under study is the pollination biology of large cardamom in the eastern Himalayas.

Very little research has been carried out on the pollination of large cardamom by bees, especially by the indigenous honey bees Apis cerana subsp. cerana, Apis cerana subsp. himalayana, A. dorsata, and A. laboriosa. A. cerana naturally occurs in climatic zones ranging from rainforest, savanna, steppe, grasslands and deciduous forest to taiga (Radloff et al. 2010) and occurs all along the cardamom growing altitudes (600-2300 m) in the eastern Himalayas. Even though they can cover large distances and are very manageable even at a homestead level, they become well suited for pollination of large mono-crops (Martin and Farina 2016) and large cardamom mono-crop is not an exception. The low productivity of large cardamom could be attributed to declining pollinator species leading to inadequate pollination of the large cardamom (Sharma 2013; Partap et al. 2014; Sharma et al. 2016b).

We hypothesized that honey bees could also contribute to pollination in large cardamom flowers, similar to bumble bees. Therefore, the basic objective to prove this hypothesis was to assess (i) visitation frequency and foraging behaviour of honey bees and bumble bees in cardamom flowers, (ii) pollination and foraging dynamics of both the bees, and (iii) the yield estimation in relation to pollinator visitation.

\section{Materials and methods}

\section{Large cardamom agroforestry systems}

We selected well flourished large cardamom agroforestry systems for the study. Large cardamom-based agroforestry is categorized into two sub systems: Alnus-cardamom and forest- cardamom systems. Large cardamom is a high value cash-crop which, when properly cured, stores well for extended periods. Large cardamom generally produces low volume per plant, but the trade-off is that it requires relatively low labour inputs. Himalayan alder (Alnus nepalensis) is a naturally occurring tree associate with cardamom, valued for its ability to provide appropriate shade, fix atmospheric $\mathrm{N}_{2}$, and generate nutrient rich litter which helps facilitate a more efficient cycling of nutrients (Sharma et al. 2008, 2010). Scientific understanding following adequate analysis of large cardamom agroforestry systems have proven this traditional practice as economically remunerative, ecologically adapted, with comparatively high carbon sequestration potential while pollination biology is yet to be fully understood (Sharma et al. 2016a, b, c).

\section{Location and climate of study sites}

Three study sites $\left(27^{\circ} 11^{\prime} 46^{\prime \prime} \mathrm{N} ; 88^{\circ} 13^{\prime} 15^{\prime \prime} \mathrm{E}\right)$ viz., LingeePayong (1100 m), South Sikkim, Hee-Martam (1500 m) in West District, and Jaubari (2000 m) in South Sikkim were identified for the study which have been considered as the main large cardamom growing areas in Sikkim. The agroclimatic conditions of these areas are also conducive to the cultivation of a large number of other cash crops such as mandarin oranges, ginger, potatoes, broom grass, and a diverse array of horticultural crops. Keeping in mind the heterogeneity of the agroclimatic conditions along the vertical elevations, the farmers in Sikkim cultivate a diversity of crops including paddy, maize, finger millet, buckwheat, wheat, yams and other tubers, oilseeds, and vegetables in the lower elevations and maize, potatoes, cabbage, and cauliflower at higher altitudes.

The average annual rainfall across the study sites is $3500 \mathrm{~mm}$, with higher rates $(2000-4000 \mathrm{~mm})$ at higher altitudes and lower rates at lower altitudes (1000-2000 mm). The study sites mostly face south-west with a slope range of $20-45^{\circ}$. The sites of Jaubari, upper reaches of HeeMartam, and Sokpay area in Lingee-Payong experience occasional snowfall and frost during winter. The ambient air temperature ranges from 6 to $20^{\circ} \mathrm{C}$ in the higher elevations and $10-27{ }^{\circ} \mathrm{C}$ in the lower sites (Table 1). Humidity ranges from 60 to $99 \%$ across all sites. 
Table 1 Stand characteristics of the study sites

\begin{tabular}{|c|c|c|c|c|c|c|c|}
\hline Study sites & Location & $\begin{array}{l}\text { Elevation } \\
(\mathrm{m})\end{array}$ & Slope $\left(^{\circ}\right)$ & Aspect & Flowering Season & Harvesting season & $\begin{array}{l}\text { Local Variety (car- } \\
\text { damom) }\end{array}$ \\
\hline Lingee-Payong & $\begin{array}{l}27^{\circ} 21^{\prime} 40^{\prime \prime} \mathrm{N} 88^{\circ} 27^{\prime} \\
54^{\prime \prime} \mathrm{E}\end{array}$ & 1100 & $20-30$ & South facing & 1 April-30 May & August-September & Ramsai \\
\hline Hee-Martam & $\begin{array}{l}27^{\circ} 15^{\prime} 09^{\prime \prime} \mathrm{N} 88^{\circ} 13^{\prime} \\
15^{\prime \prime} \mathrm{E}\end{array}$ & 1500 & $30-40$ & North facing & 15 April-15 June & September-October & Ramsai, Seremna \\
\hline Jaubari, Namchi & $\begin{array}{l}27^{\circ} 11^{\prime} 46^{\prime \prime} \mathrm{N} 88^{\circ} 23^{\prime} \\
31^{\prime \prime} \mathrm{E}\end{array}$ & 2000 & $35-45$ & West facing & 15 May-15 July & November & Ramsai \\
\hline
\end{tabular}

\section{Experiment design}

We placed honey bees colonies in each of the large cardamom plantations; 3 April 2016 at Lingee-Payong, 13 April 2016 at Hee-Martam and 16 May 2016 at Jaubari, respectively, following the flowering season based on Chaudhary and Kumar (2000). We marked plots of $3 \times 4 \mathrm{~m}$ area each for $50 \mathrm{~m}$ and $250 \mathrm{~m}$ stands (total 6 plots, $2 \times 3$ sites). We counted the number of bushes and number of spikes bearing the flowers within each plot. The number of flowers opened each day and the foraging behavior of honey/bumble bees within $50 \mathrm{~m}$ and $250 \mathrm{~m}$ stands were recorded. We established a control net experiment by placing a nylon-net $(<1 \mathrm{~mm}$ size $)$ in $2 \times 2 \mathrm{~m}$ plot to study pollination without allowing the bees or insects to visit the cardamom flowers.

Across study sites, a temporal difference in the flowering and harvesting season of large cardamom were recorded. Flowering started from the middle of March through late May in the lower altitude (600-1000 m) and April through June at the middle altitude (1100-1500 m), and at the high altitude (1600-2300 m) flowering started by third week of June and continued until early August.

\section{Foraging study}

Foraging behavior was recorded at 9:00-11:00, 12:00-14:00, and 15:00-17:00 $\mathrm{h}$ of the day. For quantitative studies-visitation frequency and foraging time of bees were recorded within the marked plots. Time spent by bees in the flowers, number of visits, foraging behavior, their movement in flowers, touching of the stigma, pollen collection, nectar collection, number of bees reaching the honey bees colony with pollen loads etc., in three time slots of the day were recorded within $50 \mathrm{~m}$ and $250 \mathrm{~m}$ stands.

The number of visits per flower per unit time represents visitation frequency. The pollinator density for both honey bees and bumble bees were recorded in $3 \times 4 \mathrm{~m}$ plots across the study sites and repeated in four consecutive days. The foraging dynamics of floral visitors was studied based on their landing pattern on flowers, approach towards pollen and nectar sites and probability of pollinating the stigma.

\section{Yield estimation}

Yield estimation was done in the marked area $\left(12 \mathrm{~m}^{2}\right)$ separately within $50 \mathrm{~m}$, and $250 \mathrm{~m}$ stand, and in control $\left(4 \mathrm{~m}^{2}\right)$. We harvested mature spikes to obtain fruit set (capsule) on 19 August, 22 September and 8 November 2016 at LingeePayong, Hee-Martam and Jaubari, respectively. Matured capsules were carefully segregated; fresh weights of the capsules were recorded and dried in a hot air oven (TestMaster ITC-902 M) at $60{ }^{\circ} \mathrm{C}$ to constant weight. Dry weight of the capsules and seeds was measured using high precision electronic balance (Sartorius BP121S). Number of seeds per capsule (seed set), weight of the capsule, and weight of the seeds was recorded.

\section{Statistical analysis}

We used MS-Excel 2007, SPSS $10 \mathrm{~V}$ and Systat $10.0 \mathrm{~V}$ for statistical analysis. The treatments $50 \mathrm{~m}$ within the honey bees colony, $250 \mathrm{~m}$ away from the colony and control were compared using Multi Factor Analysis of Variance, independent samples $t$-test comparison and regression analysis. However, the available data were transformed before analysis using arcsine and represented back in the table as in original form.

\section{Results}

\section{Cardamom flower visitors}

More than $98 \%$ of visitors of cardamom flowers across sites and stands were Bombus braviceps, Bombus haemorrhoidalis, and indigenous Apis spp. We also observed hoverfly (Episyrphus balteatus), Crimson Sunbird (Aethopyga siparaja), and moths (Udasees folus) occasionally visiting the flowers.

\section{Visitation frequency}

Visitation of pollinators was dependent on ambient air temperature; it varied along the time slots from morning 
to evening and along the elevations. Bumble bees started floral visits at $6: 00 \mathrm{~h}$ while honey bees visits started by 7:00 h. Bee visits were highest during 9:00-11:00 h, slightly low at 11:00-13:00 $\mathrm{h}$ and lowest at 15:00-16:00 $\mathrm{h}$ (Fig. 1). Bee visits was significantly low at high altitude (Jaubari) than mid (Hee-Martam) and low altitudes (Lingee-Payong). Honey bees showed the highest number of floral visits $\left(19.24 \pm 4.23\right.$ per $\left.12 \mathrm{~m}^{2}\right)$ than bumble bees $\left(13.87 \pm 3.12\right.$ per $\left.12 \mathrm{~m}^{2}\right)$ within $50 \mathrm{~m}$. Bumble bees visitations $\left(20.57 \pm 5.31\right.$ per $\left.12 \mathrm{~m}^{2}\right)$ were higher than honey bees at $250 \mathrm{~m}\left(9.44 \pm 2.54\right.$ per $\left.12 \mathrm{~m}^{2}\right)$ (Fig. 1).

Multi-factor analysis of variance showed significant difference between sites, treatments and time slots $(P<0.001)$ for both bees. Interaction between sites and time slots for both bees was found significant $(P<0.001)$. Similarly, interaction between sites, treatment and time slots showed significantly for both bees. Visitation of honey bees was almost nil during cold mornings, evenings, and on rainy days, but it was more on bright sunny days. Floral visits per unit area were highest at the low altitude
(Lingee-Payong), high at mid (Hee-Martam) and lowest at high attitude (Jaubari).

\section{Time spent by pollinators in cardamom flowers}

Time spent in large cardamom flowers during nectar extraction/foraging across sites and treatments by honey bees was higher (ranged 12.87-36.25 s flower ${ }^{-1}$ ) than bumble bees (ranged 4.60-27.80 s flower ${ }^{-1}$ ) (Table 2). While, time spent by both the bees was comparatively high in the midelevation as compared to high and low altitudes. Also, the time spent by honey bees was significantly high $(t=0.675$, $P \leq 0.001)$ within $50 \mathrm{~m}\left(14.20-36.25 \mathrm{~s} \mathrm{flower}^{-1}\right)$, and less $\left(12.25-32.83 \mathrm{~s}\right.$ flower $\left.^{-1}\right)$ at $250 \mathrm{~m}$ across sites. Interestingly, bumble bees visitation frequency was higher $(t=3.22$, $P \leq 0.001)$ at $250 \mathrm{~m}\left(3.90-27.80 \mathrm{~s}\right.$ flower $\left.^{-1}\right)$ than $50 \mathrm{~m}$ $\left(3.70-17.75 \mathrm{~s}\right.$ flower $\left.^{-1}\right)$. Multiple-analysis of variance showed significant variation between study sites, treatments and time slots (Table 2).
Fig. 1 Variation of number bee visits (Honey bees $=$ red, Bumble bees $=$ blue) to large cardamom flowers across sites, treatments and time slots. Values are $\pm \mathrm{SE}, n=27$. Multi-ANOVA Bees density. Honey bees: Sites: $F_{2339}=40.76, P<0.001$; Treatments: $F_{1340}=3.24, P<0.001$; Time slots: $F_{2339}=19.56$, $P<0.001$; Interaction: Site x Time slots: $F_{4333}=7.49$, $P<0.001$; Time slots $\mathrm{x}$ Treatment: NS; Site $x$ Time slots x Treatments: $F_{14,327}=20.03$, $P<0.001$. Bumble bees: Sites: $F_{2339}=7.60, P<0.001$; Treatments: $F_{1340}=17.58, P<0.001$; Time slots: $F_{2339}=6.18$, $P<0.001$; Time slots $\mathrm{x}$ Treatment: NS; Interaction: Site $\mathrm{x}$ Time slots $\mathrm{x}$ Treatments: $F_{14,327}=3.92, P<0.001$
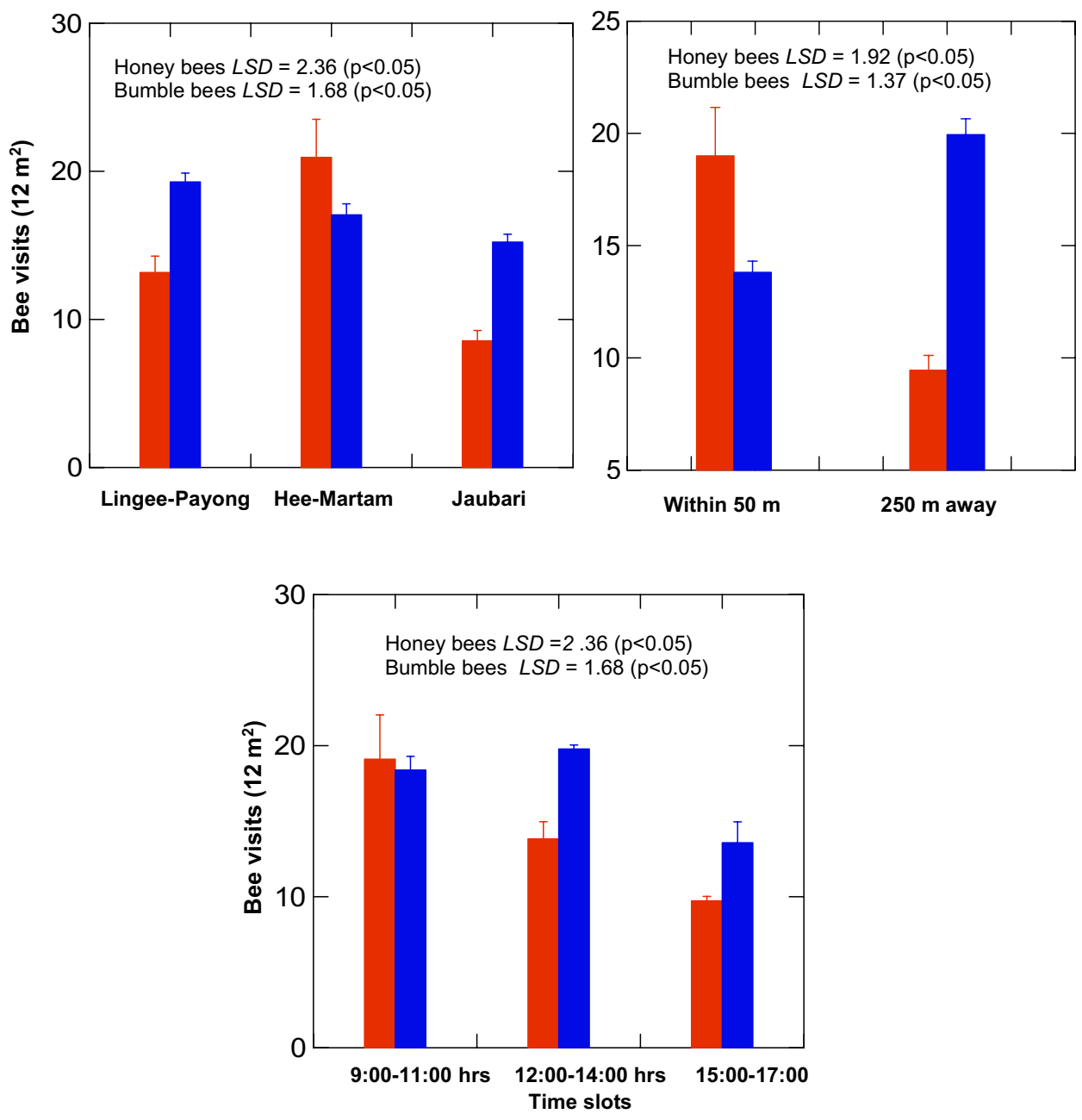
Table 2 Foraging time $\left(\mathrm{sec}\right.$ flower ${ }^{-1}$ ) spent by bees in cardamom flowers within $50 \mathrm{~m}$ of honey bees colony and $250 \mathrm{~m}$ away from it across sites

\begin{tabular}{|c|c|c|c|c|}
\hline \multirow[t]{2}{*}{ Study sites (time slots) } & \multicolumn{2}{|l|}{ Honey bees } & \multicolumn{2}{|l|}{ Bumble bees } \\
\hline & $50 \mathrm{~m}$ & $250 \mathrm{~m}$ away & $50 \mathrm{~m}$ & $250 \mathrm{~m}$ away \\
\hline \multicolumn{5}{|l|}{ Lingee-Payong } \\
\hline 9:00-11:00 & $15.55 \pm 1.39$ & $15.00 \pm 1.43$ & $7.15 \pm 0.52$ & $9.55 \pm 1.21$ \\
\hline $12: 00-14: 00$ & $14.55 \pm 0.46$ & $13.75 \pm 2.09$ & $4.60 \pm 0.46$ & $5.95 \pm 0.83$ \\
\hline $15: 00-17: 00$ & $14.20 \pm 0.69$ & $12.25 \pm 1.23$ & $3.70 \pm 0.47$ & $3.90 \pm 0.24$ \\
\hline \multicolumn{5}{|l|}{ Hee-Martam } \\
\hline 9:00-11:00 & $28.36 \pm 2.32$ & $36.25 \pm 2.84$ & $14.56 \pm 0.66$ & $19.30 \pm 2.76$ \\
\hline $12: 00-14: 00$ & $20.10 \pm 2.15$ & $32.83 \pm 1.57$ & $13.10 \pm 0.89$ & $15.90 \pm 0.89$ \\
\hline $15: 00-17: 00$ & $21.10 \pm 2.19$ & $24.17 \pm 2.79$ & $17.75 \pm 0.63$ & $27.80 \pm 4.11$ \\
\hline \multicolumn{5}{|l|}{ Jaubari } \\
\hline $9: 00-11: 00$ & $15.83 \pm 0.76$ & $12.88 \pm 1.16$ & $7.35 \pm 0.68$ & $7.55 \pm 1.63$ \\
\hline $12: 00-14: 00$ & $15.65 \pm 1.08$ & $15.375 \pm 1.65$ & $6.35 \pm 0.57$ & $9.35 \pm 0.71$ \\
\hline $15: 00-17: 00$ & $17.00 \pm 1.30$ & $12.875 \pm 1.67$ & $6.45 \pm 0.53$ & $9.20 \pm 0.52$ \\
\hline \multicolumn{5}{|l|}{ Multi-ANOVA } \\
\hline & $\begin{array}{l}F_{8,24}=10.95 \\
P<0.01\end{array}$ & $\begin{array}{l}F_{8,24}=33.34 \\
P<0.01\end{array}$ & $\begin{array}{l}F_{8,24}=80.37 \\
P<0.01\end{array}$ & $\begin{array}{l}F_{8,24}=15.56 \\
P<0.01\end{array}$ \\
\hline & $\operatorname{LSD}(P<0.05)=4.00$ & $\operatorname{LSD}(P<0.05)=4.69$ & $\operatorname{LSD}(P<0.05)=1.59$ & $L S D(P<0.05)=5.62$ \\
\hline
\end{tabular}

Values are \pm SE, $n=20$

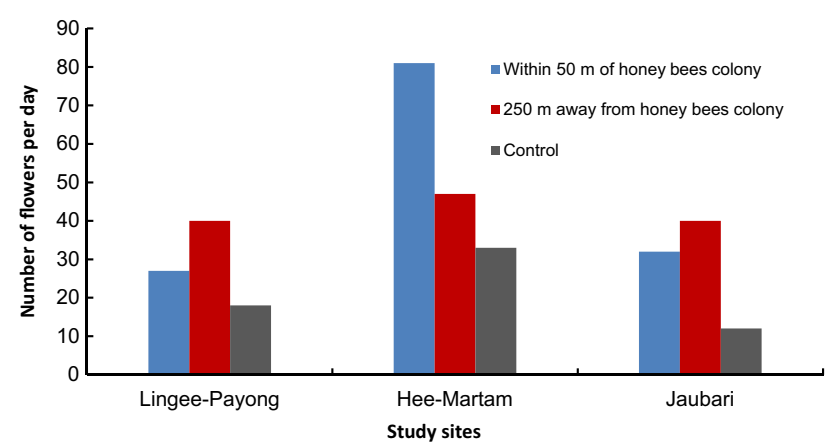

Fig. 2 Number of flowers across treatments and sites. Values are pooled from three sites

\section{Foraging behaviour}

The number of flowers differed significantly across sites and treatments (Fig. 2). During foraging, bumble bees firstly landed on the labellum and then moved deep inside the flower column to collect nectar. Both the bees collected pollens in their baskets while foraging for nectar. Comparatively, bumble bees collected 2-3 times more pollen as compared to honey bees (Fig. 3a, b). While foraging, bumble bees deplete a great deal of pollen from cardamom flowers, as its furry back brushes against the anthers. Both bees collect almost $60 \%$ of the pollens during the course of nectar extraction. Honey bees frequently landed on the stigma column of the flower from different sides (Fig. 3 c, d). Loaded with pollen all over the body, it constantly touched the stigma cup. We observed that pollens were released on the stigma cup of the flowers during foraging.

The foraging activity of both bees was highest at 9:00-11:00 $\mathrm{h}$ than in the morning and evening hours. Honey bees acted differently for nectar collection, they enter the flowers through the stigma-anther column from either side and during this movement, pollen bearing appendages were seen passing the pollen to the stigma. While bumble bees collect nectar from the flowers only through its long labellum and had pollens adhered to their back touching the stigma. Thus, both bees were observed transferring pollens to the stigma during foraging.

\section{Floral biology}

The total number of flowers ranged 27-81 (in $12 \mathrm{~m}^{2}$ ) at $50 \mathrm{~m}$, $40-47\left(12 \mathrm{~m}^{2}\right)$ at $250 \mathrm{~m}$ and $12-33\left(4 \mathrm{~m}^{2}\right)$ in control with the highest count at mid-elevation (Table 3). Analysis of variance showed significant difference between sites $(P<0.001)$, and treatments $(P<0.001)$, the interaction between sites and treatments was also significant $(P<0.001)$. The average sized spikes bearing inflorescence had 45-80 flowers (mean $62.23 \pm 15.43$ ). The number of flowers opening each day on an average sized bush was 3.8 (range 3-6) at LingeePayong, 5.9 (range 4-10) at Hee-Martam, and 4.6 (range 3-9) at Jaubari. The longevity of large cardamom flowers was one day. An average number of flowers per spike per day were 3.82, 5.94, and 4.57 for Lingee-payong, Hee-Martam 

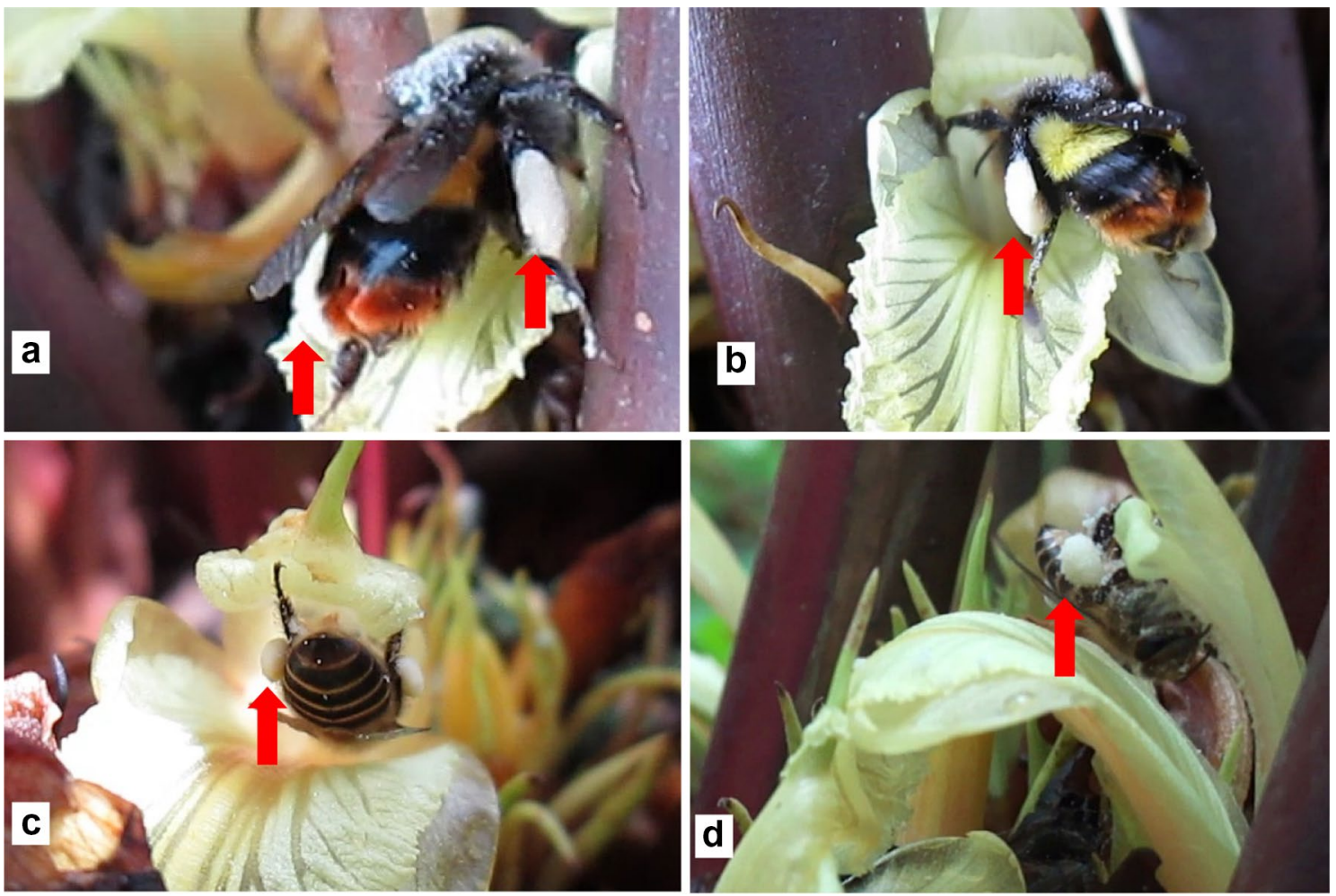

Fig. 3 Foraging dynamics of bumble bees $(\mathbf{a}, \mathbf{b})$ and honey bees $(\mathbf{c}, \mathbf{d})$, and pollen collection on their baskets while foraging on cardamom flowers

Table 3 Number of honey bees touching stigma and carrying pollen on their body hair and abdomen

\begin{tabular}{llllllll}
\hline Study site & Stands & $\begin{array}{l}\text { Total no. of } \\
\text { spikes }\left(12 \mathrm{~m}^{2}\right)\end{array}$ & $\begin{array}{l}\text { Total no. of } \\
\text { flowers } \\
\left(12 \mathrm{~m}^{2}\right)\end{array}$ & $\begin{array}{l}\text { Total no. of visit } \\
\text { of honey bees }\end{array}$ & $\begin{array}{l}\text { Honey bees } \\
\text { touching stigma } \\
(\%)\end{array}$ & $\begin{array}{l}\text { Honey bees not } \\
\text { touching stigma }(\%)\end{array}$ & $\begin{array}{l}\text { Honey bees carrying } \\
\text { pollens in baskets } \\
(\%)\end{array}$ \\
\hline Lingee-Payong & $50 \mathrm{~m}$ & 118 & 107 & 157 & $78(49.68)$ & $79(50.31)$ & $96(61)$ \\
& $250 \mathrm{~m}$ & 130 & 73 & 80 & $42(52.50)$ & $38(47.50)$ & $46(57)$ \\
Hee-Martam & $50 \mathrm{~m}$ & 68 & 324 & 239 & $122(51.01)$ & $117(48.95)$ & $98(30)$ \\
& $250 \mathrm{~m}$ & 64 & 188 & 138 & $79(57.24)$ & $59(42.75)$ & $75(39)$ \\
Jaubari & $50 \mathrm{~m}$ & 64 & 142 & 117 & $61(52.14)$ & $56(47.86)$ & $67(47)$ \\
& $250 \mathrm{~m}$ & 37 & 46 & 37 & $23(62.16)$ & $14(37.84)$ & $27(58)$ \\
\hline
\end{tabular}

Values are pooled ( 7 days $\times 3$ time slots of two hours each), $n=84$

and Jaubari, respectively. The anthesis of the flowers took place during 5:00-6:00 $\mathrm{h}$ and wilted by 17:00-18:00 h. The nectar secretion starts gradually and peaks at 9:00-12:00 h, highest number of flowers was counted during this time-slot.

\section{Pollination by honey bees}

At Hee-Martam, more than $54.12 \%$ of honey bees touched the stigma during foraging on the flowers and c $34.50 \%$ had pollen loads. Almost $90 \%$ of the honey bees had pollens attached to their appendages. Only $48.67 \%$ of them carried pollen load on their pollen-sack while the remaining
Table 4 Average number of honey bees returning to the bee-box with and without pollen loads per minute $(7: 00-14: 00 \mathrm{~h})$

\begin{tabular}{llll}
\hline Study sites & $\begin{array}{l}\text { Honey bees } \\
\text { with pollen } \\
\text { loads }\end{array}$ & $\begin{array}{l}\text { Honey bees } \\
\text { without pollen } \\
\text { loads }\end{array}$ & $\begin{array}{l}\text { Total no. of } \\
\text { honey bees }\end{array}$ \\
\hline Hee-Martam & $19.33 \pm 3.62$ & $34.33 \pm 5.81$ & $53.66 \pm 9.23$ \\
Lingee-Payong & $14.16 \pm 4.81$ & $26.66 \pm 5.81$ & $40.82 \pm 7.92$ \\
Jaubari & $11.92 \pm 3.42$ & $19.28 \pm 6.45$ & $31.20 \pm 6.78$ \\
\hline
\end{tabular}

Values are $\pm \mathrm{SE}, n=21$ 
flew away without pollen loads. At Lingee-Payong, 51.09\% Honey bees touched the stigma after touching the anther while $53.50 \%$ carried pollens. At Jaubari, 57.15\% Honey bees touched the stigma after touching the anther, while $52.50 \%$ had carried pollens (Tables 3,4 ). The visit of both bees increased with increasing number of large cardamom flowers $\left(r^{2}=0.46-0.55, P<0.001\right)$.

The total number of honey bees visits were less at $250 \mathrm{~m}$ than at the $50 \mathrm{~m}$ stands. Honey bees loaded with pollens ranged from 49.68 to $52.14 \%$ within $50 \mathrm{~m}$ of honey bees colony, while it ranged from 52.50 to $62.16 \%$ at $250 \mathrm{~m}$ stands. More than $50 \%$ of honey bees touched the stigma transferring the pollens during foraging. In all probability, these honey bees could have brought nectar instead of pollens. On

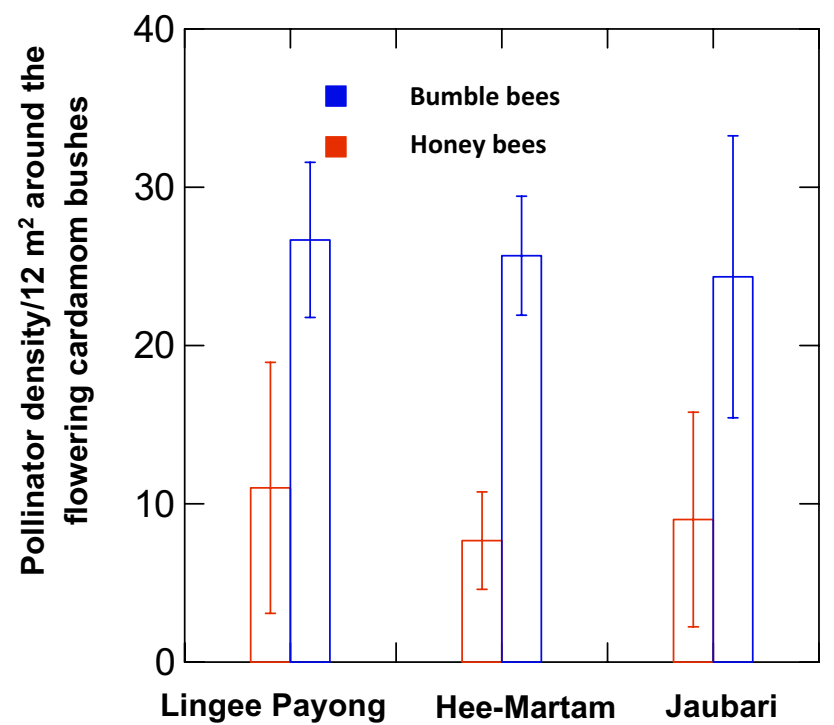

Fig. 4 Pollinator density in the study sites. Values are pooled from seven days bee count, $n=21$ an average $30-61 \%$ of the total honey bees visited the flowers with pollen in their baskets (Table 3 ). Honey bees loaded with pollen reaching the bee-box was significantly higher than those reaching the bee-box without the pollens. While among the total visits of bumble bees to the flowers, $40 \%$ visits had pollen loads, confirming that bumble bees collect both nectar and pollens. Honey bees visits during rainy days was very low $(<10 \%)$ and collected only $5 \%$ pollens, while bumble bees visit was more (20-30\%). Thus, foraging of bumble bees was high despite unfavourable conditions as compared to honey bees. Similarly, density of bumble bees was uniform across sites (Fig. 4). The average number of honey bees visits to the flowers was higher than the bumble bees across sites and time slots (Fig. 5).

\section{Fruit set, seed set and yield estimation}

Dry capsule weight harvested from $12 \mathrm{~m}^{2}$ area was highest $(1.03-1.47 \mathrm{~g})$ at $50 \mathrm{~m}$, lower at $250 \mathrm{~m}(0.8-1.33 \mathrm{~g})$, and low at control (0.62-0.92 g) (Table 5). ANOVA showed significant difference between sites, treatments and interaction between sites and treatments $(P<0.001)$. Similarly, dry weight of seed was highest $\left(1.47-1.99 \mathrm{~g} 100^{-1}\right.$ seeds) at

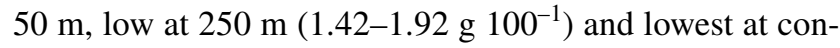

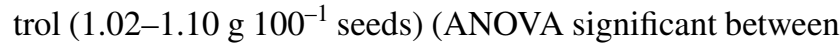
sites $P<0.001$, treatments $P<0.001$ and interaction between sites and treatments $P<0.001)$. Number of seeds per capsule was calculated and found highest (60-80 seeds) within $50 \mathrm{~m}$ distance of honey bees hive and at $250 \mathrm{~m}$ distance (40-65 seeds) as compared to control plot (2-14 seeds).

Per cent increase in a number of capsule per spike at $50 \mathrm{~m}$ over the control ranged $63.25-90.34$ and over $250 \mathrm{~m}$ stand ranged 34.84-58.03. Per cent increase of dry weight of capsules at $50 \mathrm{~m}$ over control ranged $10.67-52.24$, and in $250 \mathrm{~m}$ stand ranged 6.79-34.80 against $50 \mathrm{~m}$ stand (Table 6). Consequently, per cent seed weight increase over control ranged
Fig. 5 Comparison of the total number of times of visit of flowers by bees (honey bees and bumble bees) is different time slots across the study sites. $n=24$
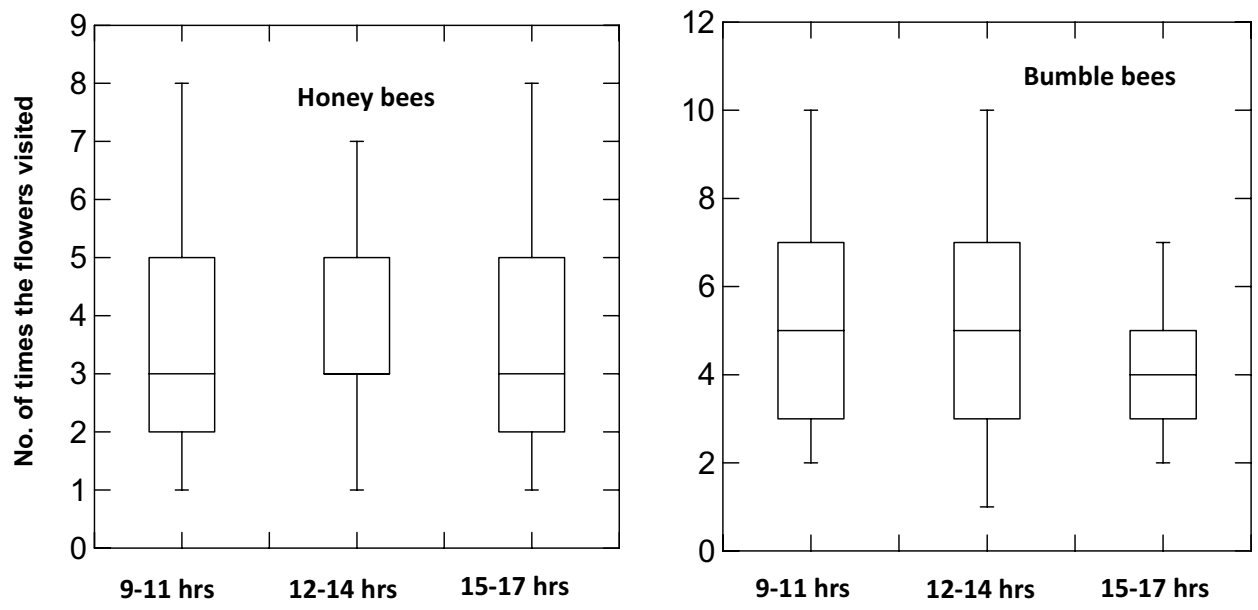
Table 5 Impact of honey bees dominated pollination within $50 \mathrm{~m}$ and bumble bees dominated (open pollinated) in $250 \mathrm{~m}$ away from the honey bees colony with respect to capsule formation and seed set

\begin{tabular}{|c|c|c|c|c|c|}
\hline Parameter & $\begin{array}{l}\text { Within } 50 \mathrm{~m} \text { of } \\
\text { honey bees colony }\end{array}$ & $\begin{array}{l}250 \mathrm{~m} \text { from honey } \\
\text { bees colony }\end{array}$ & $\begin{array}{l}\text { Control (pollina- } \\
\text { tors restricted) }\end{array}$ & $\begin{array}{l}\text { Per cent difference } \\
\text { over control }\end{array}$ & $\begin{array}{l}\text { Per cent differ- } \\
\text { ence over } 250 \mathrm{~m}\end{array}$ \\
\hline \multicolumn{6}{|l|}{ Lingee-Payong } \\
\hline No. of capsules per spike $(n=7)$ & $8.18 \pm 0.75$ & $5.33 \pm 0.75$ & $2.96 \pm 0.81$ & 3.81 & 34.84 \\
\hline Dry wt. of one capsule $(\mathrm{g}, n=50)$ & $1.34 \pm 0.08$ & $0.82 \pm 0.05$ & $0.64 \pm 0.06$ & 52.24 & 34.80 \\
\hline Dry wt. of 100 seeds $(\mathrm{g}, n=10)$ & $1.47 \pm 0.05$ & $1.42 \pm 0.05$ & $1.10 \pm 0.04$ & 25.17 & 3.40 \\
\hline \multicolumn{6}{|l|}{ Hee-Martam } \\
\hline No. of capsules per spike $(n=9)$ & $10.77 \pm 0.39$ & $4.52 \pm 0.03$ & $1.04 \pm 0.18$ & 90.34 & 58.03 \\
\hline Dry wt. of one capsule $(\mathrm{g}, n=50)$ & $1.47 \pm 0.07$ & $1.01 \pm 0.09$ & $0.89 \pm 0.14$ & 39.46 & 9.52 \\
\hline Dry wt. of 100 seeds (g, $n=10)$ & $1.64 \pm 0.03$ & $1.44 \pm 0.02$ & $1.02 \pm 0.03$ & 37.80 & 12.19 \\
\hline \multicolumn{6}{|l|}{ Jaubari } \\
\hline No. of capsules per spike $(n=9)$ & $10.07 \pm 0.76$ & $5.26 \pm 0.54$ & $3.70 \pm 0.62$ & 63.25 & 47.76 \\
\hline Dry wt. of one capsule $(\mathrm{g}, n=50)$ & $1.03 \pm 0.05$ & $0.96 \pm 0.04$ & $0.92 \pm 0.03$ & 10.67 & 6.79 \\
\hline Dry wt. of 100 seeds $(\mathrm{g}, n=10)$ & $1.99 \pm 0.04$ & $1.92 \pm 0.05$ & $1.09 \pm 0.04$ & 5.03 & 3.52 \\
\hline
\end{tabular}

\section{Multi-ANOVA}

Capsule dry wt.: Sites: $F_{2,292}=24.59, P<0.001$, LSD $(P<0.05)=0.91$; Treatments: $F_{2,292}=51.35, P<0.001$, LSD $(P<0.05)=0.90$; Interaction: Site x Treatment: $F_{4,292}=10.65, P<0.001$, LSD $(P<0.05)=0.21$. Seed $w t .: F_{2,72}=469.13, P<0.001$, LSD $(P<0.05)=0.44$; Treatments: $F_{2,72}=144.98, P<0.001, \operatorname{LSD}(P<0.05)=0.44 ;$ Interaction: Site $\mathrm{x}$ Treatment: $F_{4,72}=27.27, P<0.001, \operatorname{LSD}(P<0.05)=0.77$

Table 6 Large cardamom yield estimation across treatments and sites

\begin{tabular}{lllll}
\hline Study sites & Particulars & \multicolumn{2}{l}{ Yield estimation } & \multirow{2}{*}{ Control } \\
\cline { 2 - 3 } & & $50 \mathrm{~m}$ & $250 \mathrm{~m}$ & \\
\hline Lingee-payong & No. of spikes per bush & $9.71 \pm 0.79$ & $9.14 \pm 0.77$ & $11.25 \pm 1.19$ \\
& Fruit set per bush & $7.01 \pm 0.79$ & $6.86 \pm 0.74$ & $7.00 \pm 1.09$ \\
& Total no. of capsules $\left(12 \mathrm{~m}^{2}\right)$ & 438 & 297 & 119 \\
& Dry wt. of capsules $\left(\mathrm{g} 12 \mathrm{~m}^{2}\right)$ & 581 & 243 & 74 \\
\multirow{3}{*}{ Hee-Martam } & No. of spikes per bush & $16.25 \pm 0.95$ & $13.11 \pm 0.84$ & $10.25 \pm 0.65$ \\
& Fruit set/bush & $13.00 \pm 0.82$ & $9.11 \pm 0.80$ & $8.75 \pm 0.56$ \\
& Total no. of capsules $\left(12 \mathrm{~m}^{2}\right)$ & 986 & 744 & 200 \\
& Dry wt. of capsules $\left(\mathrm{g} 12 \mathrm{~m}^{2}\right)$ & 1449 & 990 & 178 \\
& No. of spikes per bush & $9.14 \pm 0.82$ & $5.29 \pm 0.42$ & $8.25 \pm 0.79$ \\
& Fruit set per bush & $7.71 \pm 0.82$ & $4.11 \pm 0.45$ & $7.75 \pm 0.74$ \\
& Total no. of capsules $\left(\mathrm{g} 12 \mathrm{~m}^{2}\right)$ & 527 & 143 & 132 \\
& Dry wt. of capsules $\left(\mathrm{g} 12 \mathrm{~m}^{2}\right)$ & 543 & 138 & 122 \\
\hline
\end{tabular}

5.03-37.80, and at $250 \mathrm{~m}$ stand and ranged 3.40-12.19 against the $50 \mathrm{~m}$ stand.

The independent samples $t$-test showed that capsule weight between 50 and $250 \mathrm{~m}$ stand differed significantly $(P<0.001)$ with higher values $\left(1.03-1.40 \mathrm{~g}\right.$ capsule $\left.{ }^{-1}\right)$ within $50 \mathrm{~m}$ than the $250 \mathrm{~m}$ stand $\left(0.96-1.05 \mathrm{~g}_{\text {capsule }}{ }^{-1}\right)$. Similarly, the capsule weight at $250 \mathrm{~m}$ stand and control also differed significantly $(P<0.001)$ with low values at the control $\left(0.82-0.92\right.$ g capsule $\left.^{-1}\right)$. One-way ANOVA showed significant difference $\left(F_{2,447}=93.115, P<0.001\right)$ between and within treatments $(50 \mathrm{~m}, 250 \mathrm{~m}$, control).

Seed weight across treatments and sites in the independent samples $t$-test showed significant differences between: $50 \mathrm{~m}$ and $250 \mathrm{~m}$ stands $(P<0.01), 50 \mathrm{~m}$ and control plot
$(P<0.001)$, and $250 \mathrm{~m}$ and control plot $(P<0.01)$. The seed weight at $50 \mathrm{~m}$ ranged $1.46-1.99 \mathrm{~g} 100^{-1}$ seeds, followed by $1.42-1.91 \mathrm{~g} 100^{-1}$ seeds at $250 \mathrm{~m}$ and $1.10-1.89 \mathrm{~g}$ $100^{-1}$ seeds at control (Table 6). ANOVA showed significant difference within treatments and between treatments $\left(F_{2,87}=9.467, P<0.001\right)$.

The number of fruit set per bush, capsules per spike, and total number of capsules in $12 \mathrm{~m}^{2}$ was highest within $50 \mathrm{~m}$, lower at $250 \mathrm{~m}$ and lowest in control. Yield estimated around $50 \mathrm{~m}$ was highest $(581,1449$, and $543 \mathrm{~g}$ ) comparatively lower $(243,990,138 \mathrm{~g})$ at $250 \mathrm{~m}$ and lowest (74, 178, $122 \mathrm{~g}$ ) in control in Lingee-Payong, Hee-Martam and Jaubari, respectively (Table 6). 


\section{Discussion}

At the wake of declining productivity of large cardamom agronomic yield and rapidly reducing plantation area, pollination biology stands out to be a topic of intense research to recommend revival measure to increase productivity of large cardamom in the entire Himalayan region.

Our study on pollination biology with establishment of honey bees colonies in the cardamom orchards revealed that pollination efficiency was noticeably higher within $50 \mathrm{~m}$ of honey bees colony than stands away at $250 \mathrm{~m}$. The visitation frequency of honey bees compared to bumble bees was higher within $50 \mathrm{~m}$ of the honey bees colony across sites. The cumulative visits at three time slots also showed that honey bees visitation was highest within $50 \mathrm{~m}$ compared to bumble bees, which is attributed to the establishment of honey bees colonies. The less number of bumble bees visits at $50 \mathrm{~m}$ stand could also be due to the presence of honey bees, and probability of less nectar availability. Time spent by honey bees in the cardamom flowers was higher than that of bumble bees. During foraging process, since movement of honey bees in the cardamom flowers was not uniform like bumble bees, which enter the flower only through the labellum, a large amount of pollen reached the stigma through the appendages of the honey bees. This situation also confirmed that there is high removal-high deposition (HRHD) as suggested for effective pollinator (Thomson and Thomson 1992; Thomson and Goodell 2001). The cumulative time spent by honey bees and by bumble bees recorded in this study was higher than that reported by Kishore et al. (2011). Thus, higher tendency of honey bees on foraging in the flowers could also result in a significant contribution to pollination.

In the large cardamom reproductive biology, floral longevity played a central role. Since the flower remains for only one day, pollination must occur right after anthesis, which occurs at morning hours (5:00-9:00 h). These critical hours of inflorescence determine the number of pollinator visits, the amount and quality of pollen received and disseminated, as well as floral display size (Harder and Johnson 2005).

This study also observed that a considerable amount of pollen was collected by bumble bees in their baskets apart from nectar collection. Contrary to the earlier reports made by Deka et al. (2011) and Sinu et al. (2011) that honey bees are pollen robbers, bumble bees are also potential pollen collectors approximately three times more than honey bees considering the size of the bumble bees and their tendency to accumulate more pollens. This finding clearly indicates that the flower visit of bumble bees are mainly for both nectar and pollen collection. A similar study by Gaira et al. (2016) supported the present study and indicated that both bees were observed to be the frequent visitors of large cardamom flowers. However, visits of bumble bees were more than honey bees during the rainy and overcast days.

Honey bees spent more time in flower during foraging than bumble bees. Thus foraging habits of both the pollinators were comparatively different as also reported by Kishore et al. (2011). Minute observation on the foraging dynamics of honey bees showed that their movements, mainly on the anther-stigma column resulted in the transfer of pollen to the stigma in the process.

Bee visits were significantly lower at Jaubari having comparatively low ambient air temperature $\left(9-12{ }^{\circ} \mathrm{C}\right)$, cold breeze, and frequent cloud cover etc., while it was high at Hee-Martam and Lingee-Payong where favourable conditions exist. Pollinator density within $50 \mathrm{~m}$ was higher than at $250 \mathrm{~m}$ stand, which was attributed to the honey bees colony. The corresponding low number of bumble bees within $50 \mathrm{~m}$ could be due to the presence of honey bees in the flowers and probably low availability of nectar.

At $250 \mathrm{~m}$ stands, higher percentage $(68.07 \%)$ of bumble bees was hovering while only half of them (31.93\%) were recorded for honey bees. Foraging behaviour of bees was highly dependent on altitudinal variation of the large cardamom agroforestry, stand ambient temperature, rainfall pattern and humidity. The favourable condition for foraging and collection of pollen loads was dependent on sunshine, temperature $\left(13-15^{\circ} \mathrm{C}\right)$ and humidity. Almost $90 \%$ of honey bees was observed carrying pollen spread over their body parts.

Fruit or capsule/seeds are the economic products obtained from large cardamom. Effective pollination is a prerequisite for fruit and seed set, and largely, determines the yield (Gaira et al. 2016). Foraging behaviour of the pollinator is the most crucial factor to bring about pollination in large cardamom. Our study indicates that the indigenous honey bees species contributes to large cardamom pollination along with bumble bees. Flower opening pattern influences the foraging behaviour and pollination efficiency of the visitors. The foraging pattern such as entering/landing, and touching different parts of flower especially the stigma indicates Apis sp. important pollinators. The pollen removal by bumble bees was almost $50-70 \%$ of the total pollen while pollen removal by honey bees was $30-40 \%$. The values recorded in this study were higher than the reports made by Kishore et al. (2012).

This study is in the conformity that both bees are pollen collectors. Among the diverse range of pollinator species, honey bees (along with bumble bees) acted as efficient pollinators of large cardamom in terms of their higher visitation frequency and aggregate yield (fruit set, capsule weight and seed weight). Less time spent in higher altitudes by the bees was attributed to location specific microclimatic conditions less suitable to pollinators owing to prolonged rainfall 
periods, low temperature, frost, increasingly large number of cloudy or rainy days, and less number of sunny days during the flowering season.

The number of capsules per stand was highest within $50 \mathrm{~m}$ stand compared to $250 \mathrm{~m}$ and control. Capsule weight also varied significantly between the treatments, with high values for those harvested from $50 \mathrm{~m}$, lower for $250 \mathrm{~m}$ and lowest from control. Fruit-sets and capsules were found rotten in the control plots. Around $70 \%$ of the capsules either did not bear seeds, had one or two immature whitish seeds or were totally wilted. This indicated that cardamom bushes under control were impeded due to having zero pollinator activity. Large cardamom is a cross-pollinated crop, due to its heterostylic nature of flowers (Deka et al. 2011), natural pollination by bees showed encouraging results.

Yield estimation under different treatments also differed significantly with high yield within $50 \mathrm{~m}$ than $250 \mathrm{~m}$ stand and control. Control stands had hardly a few fruit sets, showing that large cardamom is an insect-dependent species for effective pollination. Due to the large distance between the labellum and anther-stigma column, only large sized insects such as bumble bees can touch the lebellum during anthesis. Bumble bees enter the flower through labellum and touch the anther and stigma proportionally. Due to the smaller size of honey bees, this situation does not exist. However, the behaviour of honey bees is such that its high visitation frequency and time spent on foraging around anther-stigma column resulted in the transfer of pollens. Large cardamom and bees exhibit a mutualistic behaviour benefiting each other in the pollination process. On a single foraging trip, $A$. cerana foragers tend to collect either pollen or nectar (not both) from a single species of plant, continuing to collect pollen or nectar from that plant throughout the day (Baker 1999; Corlett 2011).

The higher density and foraging time spent by honey bees coincided with corresponding functional sex stages of large cardamom flowers. Results from our study showed that competition for reproductive resource was beneficial to increase the number capsules per spikes, number of seeds per capsule, and increased seed weight with increased capsules weight, particularly those harvested from within $50 \mathrm{~m}$ of honey bees colony against $250 \mathrm{~m}$ and in control. We noted the influence of altitude on the dynamics of the pollinators, flower number and fruit production which is also reported by Yang et al. (2014).

The microclimatic condition was best suited for pollinators to spend more time during foraging at the mid-elevation at Hee-Martam. Consequently, yield estimation in this altitude was higher than at low altitude Lingee-Payong and at high altitude Jaubari suggesting that low $\left(10-15^{\circ} \mathrm{C}\right)$ and high $\left(22-30^{\circ} \mathrm{C}\right)$ temperatures could impede the pollination process. For the seed number per capsule, the effectiveness of the honey bees was stronger than the bumble bees. On the contrary, both flower number and fructification percentage per inflorescence were influenced by pollinators' more than plant-intrinsic factors (Yang et al. 2014). Such case is also reported on Amonum maximum in Yunnan Province of Southwest China (Ren et al. 2007). The least number of fruit set and seed set in the control stands than in other treatments (cross pollination by bees) could be due to self-incompatibility (Ren et al. 2007). It is widely understood that the large cardamom crop yield depends primarily on the population density of pollinator species (Kishore et al. 2011). The fruit set and seed weight was comparatively more within the $50 \mathrm{~m}$ radius of the honey bees colony than a farm at $250 \mathrm{~m}$ away and in control confirming that yield was higher in honey bees pollinated stands. A similar study by Chaudhary and Kumar (2002) had confirmed that number of capsules per panicles, number of seeds per capsule, and seed weight was higher in honey bees pollinated stands than stands without insect pollination conforming that honey bees pollination resulted in better quality capsules of uniform shape and bigger size. Verma (1987) also had reported that the honey bees are good pollinators, in large cardamom crop, to increase the yield in the presence of honey bees hives close to the agroforestry stands.

\section{Conclusion}

This study has brought a new insight in pollination biology of large cardamom crop, confirming that pollination by honey bees, in addition to bumble bees, contribute to increased fruit and seed set of large cardamom resulting into high yield. The increased number of capsules per spike, high seed weight and increased gross yield estimated within $50 \mathrm{~m}$ stand of the honey bees colony against $250 \mathrm{~m}$ stand and in control was primarily attributed to the highest visitation frequency, time spent, foraging behaviour, and pollination by honey bees. However, scientific studies are needed on pollination biology to efficiently manage large cardamom agroforestry systems at the landscape in order to maintain the habitat quality for the pollinators to improve the pollination efficiency to ensure increasing yields.

Acknowledgement This study was funded by the International Centre for Integrated Mountain Development (ICIMOD) based in Kathmandu, to TMI India. Authors are grateful to TMI India for the facilities provided. We thank Scientist in-charge GB Pant National Institute of Himalayan Environment and Sustainable Development, Sikkim Unit for laboratory facilities. We are thankful to Dr. Eklabya Sharma, ICIMOD for his concept and technical support and Dr. Kailas Singh Gaira, GB Pant Institute for statistical analysis.

Open Access This article is licensed under a Creative Commons Attribution 4.0 International License, which permits use, sharing, adaptation, distribution and reproduction in any medium or format, as long as you give appropriate credit to the original author(s) and the source, 
provide a link to the Creative Commons licence, and indicate if changes were made. The images or other third party material in this article are included in the article's Creative Commons licence, unless indicated otherwise in a credit line to the material. If material is not included in the article's Creative Commons licence and your intended use is not permitted by statutory regulation or exceeds the permitted use, you will need to obtain permission directly from the copyright holder. To view a copy of this licence, visit http://creativecommons.org/licenses/by/4.0/.

\section{References}

Allen-Wardell G et al (1998) The potential consequences of pollinator declines on the conservation of biodiversity and stability of food crop yields. Cons Biolo 12:8-17

Baker DR (1999) Foraging and Habitat Selection by Two Species of Honey Bee near Lore Lindu National Park in Sulawesi, Indonesia. The University of Guelph, Guelph

Chapagain SP, Pathak A and Rai JK (2014) Alaichi (Cardamom): Widely cultivated and exported but limited innovations in processing and market expansion. In: Rai JK, Chapagain SP (eds) Value chain analysis of forest products in Koshi Hill districts of Nepal: Challenges and opportunities for economic growth Kathmandu. Forest Action Nepal and RRN. pp 18-39

Chaudhary OP, Kumar R (2000) Studies on honeybee foraging and pollination in cardamom (Elettaria cardamomum Maton). J Spic Arom Crops 9(1):37-42

Corlett RT (2011) Honeybees in Natural Ecosystems. In Honeybees of Asia; Hepburn HR, Radloff SE (eds) Springer-Verlag Berlin, Heidelberg, pp 215-226

Deka TN, Sudarshan MR, Saju KA (2011) New record of bumble bee, Bombus breviceps Smith as a pollinator of large cardamom. Curr Sci 100:926-928

Durbeck K, Torstan P (2010) Market survey: Medicinal and aromatic products (MAP) Nepal. Economics Consultancy Services, Deutschland

Gaira KS, Rawal RS, Singh KK (2016) Variations in pollinator density and impacts on large cardamom (Amomum subulatum Roxb.) crop yield in Sikkim Himalaya. India J Asia-Pacific Biodiv 9:17-21

Gupta PN, Naqvi AN, Mishra LN, Sen T, Nigam MC (1984) Gas chromatographic evaluation of the essential oils of different strains of Amomum subulatum Roxb. growing wild in Sikkim. Sonderdruck aus Parfumeric kodmetik 65:528-529

Harder LD, Johnson SD (2005) Adaptive plasticity of floral display size in animal-pollinated plants. Proc Royal Soc 8(272):2651-2657. https://doi.org/10.1098/rspb.2005.3268

Kishore K, Kalita H, Rinchen D, Lepcha B (2012) Evidence of functional specialization and pollination syndrome in Amomum subulatum Roxb. (Zingiberaceae). Curr Sci 103(2):193-199

Kishore K, Kalita H, Singh M, Awasthe R, Pandey B, Denzongpa R (2011) Pollination studies in large cardamom (Amomum subulatum Roxb.) of Sikkim Himalayan region of India. Sci Hortic 129:735-741

Martin CS, Farina WM (2016) Honeybee floral constancy and pollination efficiency in sunflower (Helianthus annuus ) crops for hybrid seed production. Apidolog 47:161-170

Partap U, Sharma G, Gurung MB, Chettri N, Sharma E (2014) Large cardamom farming in changing climatic and socioeconomic conditions in the Sikkim Himalayas. Published by International Centre for Integrated Mountain Development (ICIMOD) Working Paper 2014/2 pp 26
Radloff SE, Hepburn C, Hepburn HR, Fuchs S, Hadisoesilo S, Tan K, Engel MS, Kuznetsov V (2010) Population structure and classification of Apis cerana. Apidolog 41:589-601. https://doi. org/10.1051/apido/2010008

Ren PY, Liu M, Li QJ (2007) An example of flexistyly in a wild cardamom species (Amomum maximum (Zingiberaceae)). Pl Syst Evol 267:147-154

Sharma G (2013) Opportunities and challenges of large cardamom farming, beekeeping, and pollination system in Sikkim. Report submitted to International Centre for Integrated Mountain Development, Kathmandu Nepal (ICIMOD) by The Mountain Institute India, Gangtok Sikkim, India, pp 46

Sharma E, Sharma R, Sharma G, Rai SC, Sharma P, Chettri N (2008) Values and Services of nitrogen-fixing alder based cardamom agro-forestry systems in the Eastern Himalaya. In: Snelder DJ, Lasco RD (eds.) Smallholder Tree Growing for Rural Development and Environmental Services: Lessons from Asia. Springer, Netherlands

Sharma G, Sharma R, Sharma E (2010) Impact of altitudinal gradients on energetics and efficiencies of $\mathrm{N}$-fixation in alder-cardamom agroforestry systems of the Eastern Himalayas. Ecolog Res 25:1-12

Sharma G, Hunsderfer B, Singh KK (2016a) Comparative analysis on the socio-ecological and economic potentials of traditional agroforestry systems in the Sikkim Himalaya. Trop Ecol 57(4):751-764

Sharma G, Partap U, Dahal DR, Sharma DP, Sharma E (2016b) Declining large-cardamom production systems in the Sikkim Himalayas: climate change impacts, agroeconomic potential, and revival strategies. Moun Res Dev 36(3):286-298. https://doi.org/10.1659/ MRD-JOURNAL-D-14-00122.1

Sharma G, Partap U, Sharma E, Rasul G and Awasthe RK (2016b) Agrobiodiversity in the Sikkim Himalaya: Sociocultural significance, status, practices, and challenges. ICIMOD Working Paper 2016/5 Kathmandu: ICIMOD

Singh AI, Pothula AK (2013) Postharvest processing of large cardamom in the Eastern Himalaya: A review and recommendation for increasing the sustainability of a niche crop. Moun Res Dev 33(4):453-462

Singh KK, Gaira KS, Rai LK (2011) Agricultural scenario vis-à-vis the pollinator elements of the Sikkim Himalayan region. In: Arrawattia ML, Tambe S (eds) Biodiversity of Sikkim: Exploring and Conserving a Global Hotspot. Department of Information and Public Relations, Government of Sikkim, pp 429-442

Sinu PA, Shivanna KR (2007) Pollination ecology of cardamom (Elletaria cardamom) in the Wester Ghats of India. J Trop Ecol 23:493-496

Sinu PA, Kuriakose G, Shivanna KR (2011) Is the bumble bee (Bumbus haemorrhoidalis) the only pollinator of large cardamom in Central Himalayas, India. Apidolog 42:690-695

Thomson JD, Goodell K (2001) Pollen removal and deposition by honeybee and bumblebee visit to apple and almond flowers. J Appl Ecol 38:1032-1044

Thomson JD, Thomson BA (1992) Pollen presentation and viability schedule in animal pollinated plant consequences for reproductive success. In: Wyatt R (ed) Ecology and Evolution of Plant Reproduction: New Approaches. Chapman and Hall, New York, pp 1-24

Verma KS (1987) Preliminary studies on the effect of honeybees on the yield of greater cardamom. Ind Bees J 49:25-26

Yao-Wen Y, Liu Xiao-Li PuCX, Qian ZG, Guan KY (2014) The influence of altitude and latitude on breeding of Amomum tsaoko (Zingiberaceae). J Biosci Medi 2:9-17 